\title{
RalA-Binding Protein 1
}

National Cancer Institute

\section{Source}

National Cancer Institute. RalA-Binding Protein 1. NCI Thesaurus. Code C101288.

RalA-binding protein 1 ( $655 \mathrm{aa}, \sim 76 \mathrm{kDa}$ ) is encoded by the human RALBP1 gene. This protein is involved in the regulation of small molecule transport and signaling. 